University of Michigan Law School

University of Michigan Law School Scholarship Repository

Articles

Faculty Scholarship

$12-1981$

Justice, Bureaucracy, and Legal Method

Jospeh Vining

University of Michigan Law School, jvining@umich.edu

Follow this and additional works at: https://repository.law.umich.edu/articles

Part of the Courts Commons, Legal Profession Commons, and the Supreme Court of the United States Commons

Recommended Citation

Vining, Joseph. "Justice, Bureaucracy, and Legal Method." Mich. L. Rev. 80 (1981): 248-58.

This Response or Comment is brought to you for free and open access by the Faculty Scholarship at University of Michigan Law School Scholarship Repository. It has been accepted for inclusion in Articles by an authorized administrator of University of Michigan Law School Scholarship Repository. For more information, please contact mlaw.repository@umich.edu. 


\title{
COMMENTS
}

\section{JUSTICE, BUREAUCRACY, AND LEGAL METHOD}

\author{
Joseph Vining*
}

In the real world justice denied is not justice. Talking from the beginning about access to justice, rather than simply justice, emphasizes in a salutary way this commonplace of citizen and client. Justice that is inaccessible, delayed, refused does not just sit there glowing like a grail, which those separated from it may contemplate and yearn for. It is only in imagining that justice is available to someone, and in imagining what it would be like to be that someone, that one can see the thing as justice at all. To put it in economic terms, justice is not a commodity, the production of which can be analyzed apart from its distribution. Who gets justice very much determines what it is they are getting, whether, that is, it is justice.

But this said, it is also true that there must be something going on inside the legal system that makes worthwhile all the efforts to gain access to it. Justice may not be justice if someone does not have it, but someone can have all there is to have and still not have justice. There can be full access, and still no justice. Arrangements can be made so that everyone can crowd around the table, but there must be something more than cold and empty plates there. What one has access to is surely as important as the access, and it is this, the what, that I wish to talk about in this paper.

I shall be making a simple point: There are presuppositions to legal method which we all, lawyers included, are ignoring at our peril. Ignoring these presuppositions can end in failure to serve up anything to which anyone will give willing obedience, which will be treated as truly authoritative. Legal institutions are simply not effective, not efficient (again to use an economic term), unless they manage at the least to create legitimacy. They must at the least act as a source of the authoritative in secular society, and if this - the authoritative - is missing, I doubt very much that what there is access to can be called justice.

We spoke of presuppositions. There is a connection between le-

* Professor of Law, University of Michigan. B.A. 1959, Yale University; M.A. 1961, Cambridge University; J.D. 1964, Harvard University. - Ed.

This paper was originally presented as the Inaugural Lecture of the Distinguished Scholars Program on Access to Justice at the University of Windsor, and will be published in 2 WINDSOR Y.B. ACCESS TO JUST. — (1982). 
gal method and the internal structure of legal institutions. I will use as my example legal institutions in the United States. That, as one might imagine, will immediately lead me to the Supreme Court of the United States. But I think what I have to say is applicable to courts beyond the Supreme Court and on both sides of the border, for I wish to talk about practical things, structure and practice, and their relation to theoretical things, the presuppositions of legal method in our countries and culture. My thesis is that form must follow function really much more in law than in architecture. Institutional design and institutional practice in law must seek to realize, to approach in reality, the presuppositions of legal method if there is to be efficiency in any sense of the word. Legal method, I want to suggest, does not adapt to institutions. If there is no fit between the two, what we lose is law, not just an old way of doing things that we can leave behind. ${ }^{1}$

Let us turn then to method.

The method of choice in standard legal analysis is close reading and full discussion of a text. That is what lawyers distinctively do. In the United States, the texts of choice are the opinions of the federal Supreme Court. Most American lawyers gravitate toward them, with important and untraced effects upon the substance of American law. The prominence of constitutional law, for example, in the curricula of American law schools, in the strategies of our litigating lawyers, and in the thinking of American judges, may be quite as much a product of its methodological congeniality as of its substantive importance.

Supreme Court texts have a special and obvious attraction for lawyers. The forms of speech adopted in either writing or analyzing Supreme Court opinions refer to a single mind, that of "this Court." A single mind lying behind other legal texts is never quite so easy to postulate. There is also an elision of time. Time is very nearly transcended. The Court of men long dead is still "this Court." If one listens to the way a lawyer talks, what John Marshall said in 1803 is as important and relevant as what any contemporary Justice says. And the texts produced by the Supreme Court are conventionally authoritative throughout the geographical jurisdiction of the United States. Geographical reach is not necessary to a text's relevance to the task of determining what the law is on this or that question; but the breadth of the Supreme Court's jurisdiction at least helps eliminate the lawyer's ever present worry that what he is so carefully parsing and arguing from may be an aberration and of little mo-

1. There may be a presumption that man's mind adapts to change in his external circumstances and that change in external circumstance leads to, causes in some way, change in mind. But this is at best only a presumption. If it be thought a generalization, the experience of legal authority is not evidence for it. 
ment, no real evidence of anything larger and more meaningful. Working with other opinions, of state supreme courts, or federal appeals courts or district judges, or Canadian or British courts, an American lawyer is always open to the response "So what? That's their opinion, but why do you pay such attention to it?" Indeed, lawyers feel obliged to respond to the question "Why pay attention?" even if unasked, whenever they set about legal analysis using texts from a variety of courts; and in responding, they appeal, rather more than they 'would like to think, to the primitive assertion that each judge speaks as an oracle of the law. It is possible for lawyers to think themselves less exposed to a charge of primitivism if they work with statements of the Supreme Court.

But legal habits in the United States are threatened today. There is a sense among serious analysts that the Supreme Court is failing them and that the texts of choice for American legal analysis are wanting. Extraordinary open complaints are underscored by a general tone of comment and criticism which is unhappy and disrespectful. There is not contempt so much as there is distress of the kind associated with deprivation. If one listens one can hear a general murmur of dissatisfaction, punctuated by sharp cries. ${ }^{2}$

Complaint about imperfection, of course, is perennial, as is some undercurrent of disrespect. Criticism of the Warren Court was couched in terms of craftsmanship. ${ }^{3}$ Lawyers from the southern states did not respect that Court. Pre-World War II realists were most certainly contemptuous of the then-traditional legal forms. The late nineteenth century was spent fighting the foolishness of those legal fictions that are the subject of Dicey's most entertaining

2. What is said privately is stronger than what is written. Some criticism is a reflection of special concern for constitutional law, some is not; the Supreme Court is by no means exclusively a constitutional court. For examples of what is written, see $3 \mathrm{~W}$. LAFAVE, SEARCH AND Selzure \& 11.3, at 106-15 (Supp. 1981); Blasi, Bakke as Precedent: Does Mr. Justice Powell Have a Theory?, 67 CALIF. L. REv. 21 (1979); Davis \& Reynolds, Juridical Cripples: Plurality Opinions in the Supreme Court, 1974 Duke L.J. 59; Dershowitz \& Ely, Harris v. New York: Some Anxious Observations on the Candor and Logic of the Emerging Nixon Majority, 80 YALE L.J. 1198 (1971); Ely, The Wages of Crying Wolf: A Comment on Roe v. Wade, 82 YALE L.J. 920 (1973); Monaghan, Taking Supreme Court Opinions Seriously, 39 MD. L. REv. 1 (1979); Shapiro, Mr. Justice Rehnquist: A Preliminary View, 90 HARv. L. Rev. 293 (1976); White, A Response to "The Rhetoric of Powell's Bakke," 38 WASH. \& LEE L. REV. 73 (1981); Whitman, Constitutional Torts, 79 Mich. L. Rev. 5, 27 (1980); Kurland, Book Review, 47 U. CHI. L. REv. 185, $197-98$ (1979); Note, Plurality Decisions and Judicial Decisionmaking, 94 HARv. L. REv. 1127, 1127-28 (1981). See also the eloquent but guarded comments of Freund, Bickel, Ehrenhaft, Niles, Segal, Stern \& Wright, Report of the Study Group on the Caseload of the Supreme Court, 57 F.R.D. 573, 582-83 (1972), and Francis Allen's November, 1980 address at the University of Victoria, Humanistic Legal Education: The Quiet Crisis, reprinted in LAW QUADRANGLE NoTES, Spring 1981, at 25.

3. See, e.g., Hart, The Supreme Court, 1958 Term - Foreword: The Time Chart of the Justices, 73 HaRv. L. Rev. 84 (1959). But see Amold, Professor Hart's Theology, 73 Harv. L. ReV. 1298 (1960). See also Weschler, Toward Neutral Principles of Constitutional Law, 73 HARV. L. REV. I (1959). 
pages. But the restlessness today is different. It is accompanied by and points to a change of a sort not experienced before.

There is more to the complaint than that the Court's opinions too often treat other legal texts in a perfunctory way, do not engage points made in dissent, are inconsistent or poorly articulated - as if the writer of the opinion were sleepy, or hurried, or dull. Opinions now more often seem things written by no one at all. They are long, rather too long to be written by men struggling with a vast increase in caseload. 4 They are too much things of patchwork, things which seem, on their face, to express more the institutional process of their making than the thinking, feeling, and reasoning of the author and those persuaded with him. Poor craftsmanship, if that were the problem, can be cured by gradually replacing the authors of opinions with better craftsmen. The writing of opinions by no one, bureaucratic writing, is not so easy to change once it has taken hold. It is a structural matter, a consequence of and indeed embedded in the roles into which and out of which individuals move over time. There may be a quality of irreversibility about it, which we should fear as much as we fear the irreversibility of environmental change or genetic manipulation.

The real possibility of the bureaucratization of the Supreme Court is raised not merely by a reading of what is written in the name of the Court. Bureaucratization is reflected in the elaboration of the Court's institutional organization, particularly its hierarchical aspect. Condition, consequence, or cause of the change which is of real concern, the Court seems to be becoming far more complicated. Certainly it is no longer nine judges in dialogue with one another, trying to come to common ground and setting out in writing their agreements and disagreements with a special sense of the representative quality of their thinking. Each of the nine is acquiring a staff, developed from the legal secretary or research assistant of old. As the staff has grown there are indications that it is becoming layered. Chief clerks, senior clerks, and junior clerks are beginning to appear. Clerks may interview the flood of applicants for clerkships. One clerk may help to regulate access by other clerks to the Justice himself. As the staff grows and becomes layered, there is inevitably a premium upon tenure in office: Choosing replacements becomes ever more time-consuming, and specialized roles take time to learn.

Within a single generation the Justices have quadrupled the number of their law clerks. Some Justices are now asking their clerks to stay a longer time. The short stint by the bright, young, just-graduated law student, who moved into an intimate relationship

4. See, e.g., Brown Transp. Corp. v. Atcon, Inc., 439 U.S. 1014 (1978); G. CASPER \& R. Posner, The WORKLOAD of THE SUPREME CoURT (1976); Freund, Bickel, Ehrenhaft, Niles, Segal, Stern \& Wright, supra note 2. 
with an old Justice, kept him fresh, and then moved almost immediately on into his own life and career, has already begun to be replaced by a job description and a job. It appears that the nine staffs communicate directly with one another. They may be horizontally connected and reach agreements among themselves. Or they may operate more by bargain than persuasion: the fact that they do not act for themselves means that they are not in a role to which persuasion is immediately pertinent. And there may be reciprocal relationships vertically. Justices may be loyal to staff or to the expectations that make complex hierarchical organizations of individuals possible. 5

The actual operations of the Court have always been veiled and still are, and what is revealed is often dismissed as gossip or selfaggrandizement. But clerks routinely now say in private that they were the ghostwriters of one or another important opinion and that it was published with hardly a change, while studies of lower court procedures suggest that an institutional practice of assigning to staff the reading of briefs and the drafting of opinions is becoming well established. 6 However veiled the actual operations of the Supreme Court may be, we know that a large professional staff must have something to do. All are working to produce a product. And the products they are producing are the texts of choice to which American lawyers turn when they undertake legal analysis.

I suggest that as lawyers become aware of this, their confidence that through reading an opinion or set of opinions they can reach a

5. J. Oakiey \& R. Thompson, Law Clerks and the Judicial Process (1980), contains a pioneering description of the growth and use of staff within appellate courts generally and at the Supreme Court, together with an extensive bibliography of published material. See also G. CASPER \&.R. POSNER, supra note 4, at 72-73, 78-81, 108-09, 115; Freund, Bickel, Ehrenhaft, Niles, Segal, Stern \& Wright, supra note 2, at 582-83. The publication of Woodward and Armstrong's The Brethren, relying more on clerks' than Justices' descriptions of the opinion writing process, and using journalistic rather than scholarly techniques of investigation, evoked a substantial secondary literature of comment and criticism, often by former clerks, which is itself a source of information. See, e.g., Frank, The Supreme Court: The Muckrakers Return, 66 A.B.A. J. 161 (1980). For a review of that literature and citations to it, see Saphire, The Value of The Brethren: A Response to Its Critics, 58 TEXAs L. REV. 1475 (1980). A brief but widely-circulated discussion of writing by staff at a time when the size of the staff was smaller can be found in J. FranK, MARBLE PALACE 116-18 (1958). For a comparative view, see Herman, Law Clerking at the Supreme Court of Canada, 13 Osgoode Hall L.J. 279 (1975).

6. See, e.g., J. Howard, Courts of APPEALS IN THE Federal Judicial System 198, 200, 208-09, 279 (1981); J. OAKLEY \& R. ThOMPSON, supra note 5; Baier, The Law Clerks: Profile of an Institution, 26 VAND. L. REv. 1125 (1973); Kagan, Cartwright, Friedman \& Wheeler, The Evolution of State Supreme Courts, 76 MICH. L. Rev. 961, 971-73, 982 (1978); Lesinski \& Stockmeyer, Prehearing Research and Screening in the Michigan Court of Appeals: One Court's Method for Increasing Judicial Productivity, 26 VAND. L. REV. 1211 (1973); McCree, Bureaucratic Justice: An Early Warning, 129 U. PA. L. Rev. 777 (1981); Smith, A Primer of Opinion Writing for Law Clerks, 26 VAND. L. REv. 1203 (1973); Thompson, One Judge and No Judge Appellate Opinions, 50 Cal. ST. B.J. 476 (1975). See also P. Carrington, D. MEador \& M. ROSENBERG, Justice ON Appeal 44-55 (1976); D. MEador, APpellate CourTs: STAFf AND PROCESS IN THE CRISIS OF VOLUME (1974). 
mind behind those opinions must begin to fail within them. Lawyers assume that legal writing is a means of access to the legal mind. They assume that they are actually able to listen in on a dialogue undertaken on behalf of us all. To the extent the Supreme Court does become a bureaucracy, that assumption cannot be made.

Think for a moment how differently American lawyers treat opinions issued by one or another of the great federal administrative agencies, the Interstate Commerce Commission or the Federal Trade Commission, with their many employees, many layers, and complex organization charts. There is no such governing assumption, no such faith where opinions of administrative agencies are concerned. When commissioners decide a case after argument and briefing (if there is oral argument, and if it be assumed that they rather than their staff assistants read the briefs), they vote, and the vote is frequently, perhaps typically, transmitted to an opinion writing section of the agency, which is one of the many offices on the agency's organization chart. The opinion writing section prepares a justificatory and explanatory opinion for the result. If the vote had gone the other way, the same office would write the opinion. It would simply say different or opposite things. The opinion is then sent back to the commissioners or their staffs, who may read it, may amend it, may return it, or may approve it. Once approved, it is promulgated on behalf of the agency.

7. Bureaucratic writing of administrative opinions has been a subject of empirical study and lively debate in the United States at least since the enactment of the federal and state Administrative Procedure Acts. See, e.g., H.R. REP. No. 2711, 85th Cong, 2d Sess. 41 (1959); Administrative Procedure Act: Hearings on S. 1663 Before the Subcomm. on Administrative Practice and Procedure of the Senate Judiciary Comm., 88th Cong., 2d Sess. 47-63, 282-88 (1964) (statement of Robert M. Benjamin); Administrative Procedure: Hearings on S. 674, S. 675, and S. 918 Before a Subcomm. of the Senate Comm. on the Judiciary, 77th Cong., 1st Sess. 816 (1941) (statement of Dean Acheson); Special Message of President Kennedy to the 35th Congress on the Regulatory Agencies, Apr. 13, 1961, PuB. PAPERs, JoHn F. KenNedY 1961 267, 271 (1962) (based on the Landis Report); PRESIDENT's ADVISORY COUNCIL ON EXECUtive Organization, A New Regulatory Framework: RePORT ON SElected INDEPENDent Regulatory Agencies 49-50 (1971) (the Ash Report); B. Schwartz, The Professor AND THE COMMISSIONS 189-92 (1959); Cooper, Administrative Law, The Process of Decision, 44 A.B.A. J. 237 (1958); Hector, Government by Anonymity: Who Writes Our Regulatory Opinions?, 45 A.B.A. J. 1260 (1959); Westwood, The Davis Treatise: Meaning to the Practitioner, 43 MinN. L. Rev. 607, 617 (1959).

Descriptions of agency practice may be found in R. BERNER, CONSTRAINTS ON THE Regulatory Process, 61-83 (1976); W. Cary, Politics and the Regulatory Agencies 84-86 (1967) (Securities and Exchange Commission); W. Jones, Licensing of DOMESTIC AIR Transportation by the Civil Aeronautics Board, Report to the Comm. on LiCenses AND AUTHORIZATIONS OF THE ADMINISTRATIVE CONFERENCE OF THE U.S. 170-74 (1962); M. Shapiro, The Supreme Court ANd Administrative Agencies 131-33 (1968); Palamountain, The Federal Trade Commission and the Indiana Standard Case, in GoverNMENT Regulation of Business 156 (E. Bock ed. 1965); Welborn, Assigning Responsibility for Regulatory Decisions to Individual Commissioners: The Case of the ICC, 18 AD. L. REv. 13 (1966).

In American administrative law, the issues are litigated under the rubrics "institutional decisionmaking" or "the one who decides must hear." See, e.g., T.S.C. Motor Freight Lines, Inc. v. United States, 186 F. Supp. 777 (S.D. Tex. 1960), affd sub nom. Herrin Transp. Co. v. 
Would it be too harsh to say that no good lawyer would ever spend the time on these opinions that he lavishes on Supreme Court opinions? Certainly he would not look for nuance and image, or examine the structure of thought revealed, or work out developments and transformations over time, which is what American lawyers do with Supreme Court opinions. He would not think to do it, and would feel foolish if he found himself engaged in such an intense and delicate reading - as if, fresh from an immersion in Milton, he caught himself reading a corporate advertisement in the same way he had been reading Paradise Lost. The reason is not that agency decisions are unimportant. They are often of vast importance. The reason is that the texts produced by such agencies are not access to a mind behind them, and are not evidence of the workings of that mind. The texts are evidence only of what kinds of evidence it was thought necessary to produce for the purpose of giving the appearance of the workings of a mind. One knows from commissioners' votes what they did. ${ }^{8}$ But one cannot listen in on them. One does not know whether there was dialogue that produced a decision that could be said to be a common decision. One does not know whether there is any mutual influence over time. One can be sure that the commissioners themselves would not read opinions written by an opinion writing section several floors below to discover what their colleagues present or past actually thought. They would look at letters, memoranda, or notes of conversation. Those would be their texts.

It may be acknowledged that lawyers who challenge administrative action in court in the United States do behave as if the opinions of the great agencies written in bureaucratic fashion have independent significance. Actually, challenging lawyers begin on a rather different tack, which is not taken with judicial opinions. Initially they will try to show if they can either some ex parte influence upon what is written or some forbidden consultation between investigatory, prosecutory and opinion-writing officials within the agency, and in this part of their analysis or brief the administrative opinion will be viewed and portrayed as if it were the product of a machine, rather like one of the credit card letters churned out by computers and mailed to us so frequently these days. Their search is for circuits that went awry, "inputs" that were wrong. But if defending lawyers build a good enough wall around the process to keep the challenger from seeing into it, or successfully defend its design and working in the

United States, 366 U.S. 419 (1961); Mazza v. Cavicchia, 15 N.J. 498, 105 A.2d 545 (1954); B. Schwartz, Administrative LAw 494-510 (1977); Gifford, The Morgan Cases: A Retrospective View, 30 AD. L. REv. 237 (1978).

8. One knows what they did if it be assumed that they did more than follow their staffs' advice. If not, then as in the case of the later Merovingian kings (the famous rois fainéants) there is no clear sense in which it is they who do what is done. 
particular instance, the challenging lawyer will shift and will indeed portray the opinion as if it were a judicial opinion. The argument will then be about the nature and adequacy of the reasoning set forth, connection between basis and conclusion, consistency with prior decisions, distinction between what was essential and what peripheral in prior decisions, and interpretation of majority writings in light of points made in dissents. Both challenger and defender will use these and all the other techniques of textual analysis used by lawyers to establish what the law is and to criticize and defend particular statements of it.

Such activity on judicial review of administrative action does presume and imply a search for a unifying mind. But it does not mean that there is any belief in such a mind on the part of lawyers, even what might be called a working belief or suspension of disbelief. It does not mean that the view of the text - as opposed to its portrayal - has shifted away from that adopted in the first part of a standard challenge, that is, the view of the bureaucratic opinion as the product of a machine. Lawyers' use of these techniques of textual analysis in working with the texts produced by a bureaucracy is behavior which is either conventional or strategic. It is conventional, as a prelude to argument about matters of policy that could be discussed regardless of the existence of an opinion, conventional in the sense that salutations in letters are conventional, particularly if they are elaborate. It is strategic in that lawyers do it because it might just work. A showing of breaks in the chain of reasoning or of inconsis-" tency without justification might lead judges, under an illusion that they were dealing with the workings of a mind, to reverse and remand as they would if they were reviewing a lower court. There is no necessity for lawyers' commitment to the convention or to the implications of the strategic stance they take, for in challenging decisions of administrative agencies there are many routes to follow other than legal argument before courts. Negotiation with the agency is always possible, as is delay, appeal to congressional committees, influencing the agency's budget, and involvement in electoral politics. Because argument from texts is but one string to the bow, lawyers can afford to think of what they do as simply strategic.

But if the text, the opinion, was all there was - as is almost the case on the judicial side - could lawyers afford to be strategic? To the extent they are strategic, they are dealing with nothing that has authority or meaning for them. Can lawyers do without authority? Can any of us? Suppose lawyers decided to give the text authority. Could they pretend that the opinion is something it is not, that this product of many hands is the speech of a mind that can command their attention? Can lawyers live without authority and meaning, or supply it by pretense and presumption? Can any of us? 
Let me just touch upon what we might expect to find if Supreme Court opinions were to be perceived as only the outcomes of a system or process, and the Court itself were to be seen as a little bureaucratic system. Consider the common reaction to computers and other complex machines that order our lives. The touch-tone dialing system uses music (or at least tones in sequence) to convey information to its vast and complex center. We are often shown the place on television advertisements. It is a room filled with whirring wheels and blinking lights, and we are shown, as in a painting by Magritte, the backs of the heads of human beings in the room, who face, as we do, the banks of machinery. At a telephone in a dimly lit college dormitory a student with a panpipe plays a little tune which gains him entry to the system and a free call to a friend three thousand miles away. The student has the key to the system. He knows its secret. What is the common attitude toward the student and what he has managed to do? What is your attitude, really? Is there not an element of delight in it, just a little desire to applaud? Does it immediately seem to you that he is a thief?

When we do not pay our credit card bills exactly on time, a computer begins to speak to us. Messages are printed out, beginning with gentle reminders and then becoming darker and more ominous as time goes on, with words like "please," "appreciate," and "thank you" progressively deleted, until in the end there are sharp threats contained in a personal letter addressed to us in a separate envelope - just before we pay. What is the common attitude toward a fulminating computer creditor? What is your attitude, really? Do you pay attention to it, as you would pay attention to the command or plea of a person? Do you warm to the politeness and concern expressed in the early messages, or quiver at the threats and sternness programmed into the last? Do you feel badly that the computer had to print out a special letter to you? Or are you moved only by the thought that at some point the computer may put a black mark on your credit rating for tardy payment, and otherwise look entirely to your own convenience, when it is you pay your bills, when you can get to the bank, and the like?

In these instances and others I think you and I could summon up - cheating on computerized tests, or taking advantage of pricing mistakes in large supermarkets - there appears a striking loss of the sense of obligation. And in each of them individuals are dealing, or sense that they are dealing, with a mindless system. It does not have authority for them. They react to it, and are interested in what it might do to them. But they do not internalize its purposes, or listen really to what it says to them. Lawyers are not likely to be any different when they deal with what they think to be a mindless system 
or with a mind, if mind there be, that is hidden, a secret mind. 9

Now, some of you may think that this is simply a worry taken too far, the finding of a special difficulty in what is really a general condition of things that ever has been and always will be. It may be suggested that what I have said about the problem for legal analysis posed by the possibility of a bureaucratized Supreme Court applies to any written document, any piece of legislation, to papal bulls, histories, even standard philosophical works. Anyone who has had anything to do with the publication of books will have been struck by the extent to which books can be the product of many hands, of research assistants, friendly critics of the manuscript, professional readers, editors, copy-editors. One look at the facsimile ${ }^{10}$ of Ezra Pound's editorial work on The Wasteland tells us how endemic this is: poetry itself is not exempt. The question could be asked, then, must we not always jump over how a work is produced and treat it as an integrated whole that can stand on its own?

I do not think so. In the case of a poem or an essay or a book, we ordinarily assume that there is a single guiding mind controlling its creation. ${ }^{11}$ Pound sent the changed Wasteland back to Eliot, not on to the printer. Sentences, forms of expression, even ideas that are not originally the author's own become his by adoption, because he actually, and I emphasize actually, considers them, sentence by sentence, phrase by phrase, thought by thought, comma by comma, and makes them his own after deliberation. To the extent that he does not, they mar the piece, and the process of reading, close reading, will involve pruning them away, putting them aside, and not hearing them. To be sure, there is legislation with its special claim to our respect. But other pieces of writing - and perhaps legislation too exert their authority over us and command our respect and serious attention because and to the extent that we hear a person speaking through them. Their authority rests upon the sense of mind behind

9. In administrative law a judicial analogy for a challenged administrative practice is usually enough to save the administrative practice. But as judicial practice approximates more and more the administrative, judicial practice can no longer serve as the touchstone of legitimacy. Whatever the place of illusion in life or in law, cf. Arnold, supra note 3, at 1311, lawyers seem aware of the contrast between the presuppositions brought to the reading of judicial texts and those brought to texts bureaucratically produced in administrative agencies, and of the difficulty of maintaining the presuppositions of legal analysis as judicial practice moves toward the administrative. And it is of interest that when there is reference to the problem and to the losses that can be foreseen, terms such as "disenchantment" are used to explain what is meant. See, e.g., Carrington, The Dangers of Judicial Delegation: Concluding Remarks, 52 F.R.D. 76, 78 (1971); Remarks of Justice William H. Rehnquist, American Bar Association, Section of Administrative Law, Bicentennial Institute, Mar. 18, 1976, Transcript 98-106, reprinted in ADMINISTRATIVE LAW, supra note 7, at 494-95.

10. The Waste Land: a Facsimile and Transcript of the Original Drafts InCLUding the ANNOtations of EzRa Pound (Valerie Eliot ed. 1971).

11. The fact that one cannot ask an author for a spoken explanation of a written text, or that an explanation of a written text might take the form of slowly reading through it aloud, does not mean at all that there is no mind behind it. 
them. The Ancient Mariner exerted power over the wedding guest. $\mathrm{He}$ "held him with his glittering eye." Writings do the same with us, if they hold us at all.

What then are we to do in the United States if the Supreme Court no longer looks at us with a glittering eye? How would legal analysis be done if Supreme Court opinions came to resemble the opinions of a large administrative agency? The question is a real one, and an important one, at least in the United States, and I think it is one that should now be pursued. The courts are among the last of the great voices to be rationalized, detached from substance and reduced to process, as a result of that pursuit of objectivity outside ourselves which has produced both the radical individualism and the impersonal bureaucracy we know today. The bureaucratization of courts may not come to pass. The reality of the possibility may jolt us all into more attention to the underpinnings of law. There may in fact be a choice to be made between the authoritative and the authoritarian, and when we or those who come after us look back, it may be clear that it is we who have made the choice. No doubt we will move incrementally in institutional change, since this is a basic matter, and what emerges will not be conceived by any of us now alive. But growth in a particular direction is not inevitable.

It is time to ask again why lawyers do what they do when constructing an authoritative statement of law. We can begin by looking anew at the connections and distinctions between lawyers and the practitioners of other disciplines - all disciplines, not just the social sciences to which we have recently attended. It is time to ask whether there can be any alternative to the method lawyers use. Only then will we and our successors be in a position to consider, with a sense of what is truly at stake, the design and redesign of the institutional structure expressing and making possible what lawyers do when they are asked to supply legitimacy to the world. 